\title{
Effect of pasture versus indoor feeding systems on raw milk composition and quality over an entire lactation
}

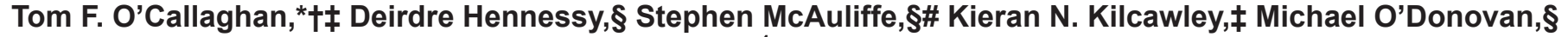 \\ Pat Dillon,§ R. Paul Ross, ${ }^{*} \dagger$ and Catherine Stanton $\ddagger^{1}$ \\ *APC Microbiome Institute, University College Cork, Cork, Ireland \\ †Department of Microbiology, University College Cork, Cork, Ireland \\ ‡Department of Biosciences, Teagasc Food Research Centre, Moorepark, Fermoy, Cork, Ireland \\ §Animal and Grassland Research and Innovation Centre, Teagasc Moorepark, Fermoy, Cork, Ireland \\ \#School of Biological Sciences, Queen's University, Belfast, BT7 1NN, United Kingdom
}

\section{ABSTRACT}

The aim of this study was to investigate the effects of different feeding systems on milk quality and composition. Fifty-four multiparous and primiparous Friesian lactating cows were divided into 3 groups $(\mathrm{n}=18)$ to study the effects of 3 feeding systems over a full lactation. Group 1 was housed indoors and offered a total mixed ration diet (TMR), group 2 was maintained outdoors on a perennial ryegrass pasture (referred to as grass), and group 3 was also grazed outdoors on a perennial ryegrass/white clover pasture (referred to as clover). Bulk milk samples were collected from each group at morning and afternoon milkings once weekly from March 11 to October 28 in 2015. Milk from pasture-fed cows (grass and clover) had significantly higher concentrations of fat, protein, true protein, and casein. The pasture feeding systems induced significantly higher concentrations of saturated fatty acids C11:0, C13:0, C15:0, C17:0, C23:0, and unsaturated fatty acids C18:2n-6 trans, C18:3n-3, C20:1, and C20:4n-6 and a greater than 2-fold increase in the conjugated linoleic acid C18:2 cis-9,trans-11 content of milk compared with that of the TMR feeding system. The TMR feeding system resulted in milks with increased concentrations of C16:0, C18:2n-6 cis, C18:3n-6 cis, C22:0 C22:1n-9, and C18:2 cis-10,trans-12. Principal component analysis of average fatty acid profiles showed clear separation of milks from the grazed pasture-based diets to that of a TMR system throughout lactation, offering further insight into the ability to verify pasture-derived milk by fatty acid profiling.

Key words: pasture, total mixed ration, milk composition, dairy cow, diet

Received February 3, 2016.

Accepted July 6, 2016.

${ }^{1}$ Corresponding author: catherine.stanton@teagasc.ie

\section{INTRODUCTION}

Farming practices are primarily dictated by a region's climate and resources. The Irish dairy industry, like that in New Zealand, has a temperate climate and is based around the use of pasture as a low-cost primary feed source (O'Brien et al., 1999); as a result, temperate regions have a seasonal milk supply. Typically, in pasture-based feeding systems, cows are maintained outdoors grazing fresh pasture during the warmer months and are dried off and housed indoors in the winter months leading up to the spring calving period. Dairy products derived from pasture-based systems are considered by consumers to be more natural because of increased animal welfare and protection of the environment (Verkerk, 2003). Pasture systems also offer cows a more natural environment, which allows the expression of normal behaviors (Legrand et al., 2009; Charlton et al., 2011). Total mixed ration, year-round indoor housing systems are widely practiced in the United States and parts of Europe as the major farming systems (van Arendonk and Liinamo, 2003; Barberg et al., 2007). Such systems involve feeding cows a TMR diet, composed of a mix of grass/maize/corn silage, carbohydrates, and concentrates, which better enable high milk production per cow through greater control of feed intake quality and increased daily DMI (Charlton et al., 2011). Indoor TMR systems also offer the cows protection from environmental extremes such as heat, cold, and wetness (Legrand et al., 2009). Such systems have been linked with animal welfare concerns such as increased lameness, reduced comfort, and an increased prevalence of mastitis, all of which can have an effect on animal production (Haskell et al., 2006; Fregonesi et al., 2007).

The effect of cows' dietary system on milk composition has received much attention in the past and it is widely accepted that feeding system has significant effects on milk fatty acid (FA) composition with par- 
ticular emphasis on the health-benefiting UFA components, particularly CLA. Examples of feeding systems that have been studied for their effects on milk include consumption of TMR (White et al., 2001), red clover (Lee et al., 2009), red clover and grass silage (Moorby et al., 2009), fresh alfalfa (Castillo et al., 2006), alfalfa silage (Whiting et al., 2004), linseed (Puppel et al., 2013), fresh forage and marine algae (Glover et al., 2012), camelina (Hurtaud and Peyraud, 2007), fish oil (Baer et al., 2001), fish oil and extruded soybeans (Ramaswamy et al., 2001), rapeseed supplementation (Stanton et al., 1997), and various proportions of fresh grass (Couvreur et al., 2006). Research has clearly identified that incorporating white clover into pasture-based diets has many benefits on dairy cow performance due to its increased nutritive value over perennial ryegrass (Ribeiro Filho et al., 2005; Egan et al., 2015; McCarthy et al., 2016). Feeding pure white clover, however, is not a feasible practice due to difficulties in maintaining such swards and increased risk of bloat (Harris et al., 1998). The clover level needed to induce a beneficial response on a cow's performance has also been studied with mixed results. Thomson (1984) indicated that clover content needed to be at least 30\%, Egan et al. (2015) found benefits at sward clover contents of $23 \%$, whereas studies performed in New Zealand reported 50 to $60 \%$ clover content to be more appropriate to increase milk yields significantly (Harris et al., 1997, 1998). Caradus et al. (1996) outlined the major benefits associated with clover feeding, which include its improved sward quality, improved forage DMI and utilization rates in animals, and effectiveness at fixing $\mathrm{N}$ in the soil.

It is understood that milk from cows consuming significant quantities of grazed grass contains higher proportions of UFA and CLA than cows that are offered diets dominated by conserved forages, concentrates, and grains (Kelly et al., 1998). Much of this research, however, was conducted over a short period using crossover studies or replicated Latin square designs. Limited information is available for the comparison of pasturebased and TMR feeding systems on the composition and quality of raw milk over an entire lactation season.

The objective of this study was to examine and assess the effects of 3 widely practiced feeding systems, namely a TMR diet indoors, perennial ryegrass (Lolium perenne L.) outdoors (GRS), and perennial ryegrass/ white clover (Trifolium repens L.) outdoors (CLV) on the composition and quality of raw milk throughout an entire lactation, and to identify potential attributes of milks that could be used to verify pasture-derived milks.

\section{MATERIALS AND METHODS}

\section{Reagents}

Hexane, heptane, formic acid, and 25\% sodium methoxide were purchased from Sigma Aldrich (Dublin, Ireland). Diethyl ether was purchased from Fisher Scientific (Dublin, Ireland). Internal standard trinonadecanoin (C19:0; part number: T-165) and a standard mix of conjugated linoleic acid C18:2 c9t11 and C18:2 c10t12 (part number: UC-59M) were purchased from $\mathrm{Nu}-$ Chek Prep Inc. (Elysian, $\mathrm{MN} ; \mathbf{c}=$ cis; $\mathbf{t}=$ trans). Fatty acid methyl ester standard mix containing C4:0 to C24:0 methyl esters (part no: 18919-1AMP) was purchased from Sigma Aldrich (Dublin, Ireland).

Experimental Design and Sample Collection. Fifty-four spring-calving Friesian cows were allocated to 3 groups (n = 18) at the Teagasc Animal and Grassland Research and Innovation Centre, Moorepark, Fermoy, Co. Cork, Ireland. The experiments were conducted between March 11 and October 28, 2015. Groups were randomized based on milk yield, milk solids yield, calving date (mean calving date February 19, 2015), and lactation number. Three feeding systems were compared over a full lactation; group 1 was housed indoors and fed a TMR diet, group 2 was maintained outdoors on perennial ryegrass only pasture (GRS), whereas group 3 was also maintained outdoors on a perennial ryegrass/ white clover pasture (CLV). The TMR diet consisted of, on a DM basis, $7.15 \mathrm{~kg}$ of grass silage, $7.15 \mathrm{~kg}$ of maize silage, and $8.3 \mathrm{~kg}$ of concentrates (see Tables 1 and 2). Cows within the TMR system were fed at $0830 \mathrm{~h}$ daily into electronically controlled Griffith Elder Mealmaster individual feed bins (Griffith Elder and Company Ltd., Suffolk, UK) and was available ad libitum. Pasturebased cows consumed $\sim 18 \mathrm{~kg}$ of DM/d (see Table 3 ) measured by pre- and postgrazing sward heights daily using the rising plate meter (Jenquip, Feilding, New Zealand), whereas pregrazing herbage mass was measured with an Etesia mower (Etesia UK Ltd., Warwick, UK). The CLV sward contained 20\% clover and was measured according to Egan et al. (2013). Milking took place at 0730 and $1530 \mathrm{~h}$ daily, and milk yields were recorded using DairyMaster milk meters (DairyMaster, Kerry, Ireland). To obtain a representative sample of milk, the cows in each of the 3 feeding systems were milked separately into designated 5,000-L refrigerated tanks. The evening milk was stored at $4^{\circ} \mathrm{C}$ overnight, to which the morning milk was then added and agitated before collection. Bulk milk samples were collected postmorning milking weekly throughout lactation $(\mathrm{n}=$ 32 ) and stored at $4^{\circ} \mathrm{C}$ before analysis. 
Table 1. Typical ingredient formulation ( $\%$ as fed) and chemical composition (\%) of TMR diet

\begin{tabular}{lc}
\hline Item $^{1}$ & \\
\hline TMR ingredient (\% as fed) & \\
Maize & 13.00 \\
Beet pulp, molassed & 15.50 \\
Soybean meal 48\% CP & 30.00 \\
Maize distillers & 12.00 \\
ACID BUF & 0.70 \\
Maize/beet min balancer & 2.50 \\
Salt & 0.50 \\
Barley (rolled) & 15.00 \\
Rapeseed meal & 7.50 \\
Megalac & 3.30 \\
Chemical composition (\%) & \\
OM & $93.50 \pm 0.94$ \\
DM & $86.76 \pm 0.75$ \\
Protein & $23.73 \pm 3.69$ \\
Fiber & $7.77 \pm 1.86$ \\
Starch & $21.49 \pm 1.93$ \\
Total sugar & $9.62 \pm 0.35$ \\
Ash & $6.50 \pm 0.94$ \\
Moisture & $13.24 \pm 0.75$ \\
NCGD & $83.35 \pm 1.15$ \\
\hline
\end{tabular}

${ }^{1}$ ACID BUF $=$ acid buffer; NCGD = neutral cellulase plus gamanase digestibility; Megalac, Volac Ireland, Co. Cavan, Ireland.

Ethical Approval. Teagasc has both an animal welfare body and animal ethics committee. The animal welfare body is a legal requirement of Article 26 of Directive 2010/63/EU and Regulation 50 of S.I. No. 543 of 2012. The Health Products Regulatory Authority provided project authorization, and the Health Products Regulatory Authority License number for this project is AE19132/P019.

\section{Milk and Feed Compositional Analysis}

Total nitrogen (TN), CP, NPN, noncasein nitrogen $(\mathbf{N C N})$, and true protein (TP) were determined as outlined in ISO $(2001,2004)$ using the Kjeldahl method and a nitrogen-to-milk protein conversion factor of 6.38 . These $\mathrm{N}$ values were then used to calculate $\mathrm{TP}$, casein protein $\left(\mathbf{C}_{\mathrm{p}}\right)$, and whey protein $\left(\mathbf{W}_{\mathbf{p}}\right)$ contents as outlined by Auldist et al. (1998) where TP $=\mathrm{TN}-\mathrm{NPN} \times$ $6.38, \mathrm{C}_{\mathrm{p}}=(\mathrm{TN}-\mathrm{NCN}) \times 6.38$, and $\mathrm{W}_{\mathrm{p}}=(\mathrm{NCN}-\mathrm{NPN})$ $\times 6$.38. Milk samples were analyzed for fat, lactose, and TS contents by infrared absorption spectroscopy using a FT6000 Milkoscan (Foss Ireland Ltd., Dublin, Ireland). Feed samples were collected throughout lactation from paddocks at time of grazing. Grass silage samples were collected weekly. Samples were dried at $60^{\circ} \mathrm{C}$ for $48 \mathrm{~h}$, milled, and stored before analysis. Samples were analyzed using near-infrared reflectance spectroscopy using a FOSS 6500 (FOSS Ireland Ltd.). The UFL (unité fourragère lait), PDIA (sum of the feed protein ruminally undegraded and truly digested in the small intestine), PDIE (sum of PDIA and the microbial
Table 2. Chemical composition $(\mathrm{g} / \mathrm{kg}$ of $\mathrm{DM}$; mean $\pm \mathrm{SD})$ and nutritional content of silages from TMR diet (grass silage and maize silage) collected weekly throughout lactation analyzed by near-infrared spectroscopy

\begin{tabular}{lcc}
\hline Item $^{1}$ & Grass silage & Maize silage \\
\hline DM & $389.37 \pm 61.35$ & $343.03 \pm 43.45$ \\
OM & $917.94 \pm 7.45$ & $972.53 \pm 3.22$ \\
CP & $114.55 \pm 12.55$ & $68.97 \pm 9.91$ \\
Starch & $\mathrm{NA}^{2}$ & $285.37 \pm 28.81$ \\
ADF & $296.82 \pm 23.40$ & $\mathrm{NA}$ \\
NDF & $452.02 \pm 39.31$ & $434.80 \pm 49.57$ \\
Ash & $82.06 \pm 6.75$ & $27.47 \pm 3.22$ \\
UFL (/kg of DM) & $0.93 \pm 0.04$ & $1.00 \pm 0.02$ \\
PDIA (/kg of DM) & $24.55 \pm 1.63$ & $14.97 \pm 2.20$ \\
PDIE (/kg of DM) & $68.07 \pm 2.23$ & $66.57 \pm 3.14$ \\
PDIN (/kg of DM) & $72.52 \pm 5.11$ & $42.37 \pm 6.05$ \\
\hline
\end{tabular}

${ }^{1} \mathrm{UFL}=$ unité fourragère lait; PDIA $=$ sum of the feed protein ruminally undegraded and truly digested in the small intestine; PDIE = sum of PDIA and the microbial true protein that is truly digested in the small intestine (PDIM) when energy is limiting; PDIN = sum of PDIA and PDIM when nitrogen is limiting.

${ }^{2} \mathrm{NA}=$ not available.

true protein that is truly digested in the small intestine when energy is limiting), PDIN (sum of PDIA and the microbial true protein that is truly digested in the small intestine when nitrogen is limiting) were calculated according to the INRA feeding system equations (INRA, 2007). Analysis of maize silage was carried out by FBA Laboratories Ltd. (Co. Waterford, Ireland).

\section{Milk Fatty Acid Analysis}

Lipid Extraction. Lipid extraction was performed as per the procedure outlined by De Jong and Badings (1990). Briefly, $10 \mathrm{~mL}$ of ethanol (98\% purity) was added to $10 \mathrm{~mL}$ of milk, and $1 \mathrm{~mL}$ of $2.5 \mathrm{M} \mathrm{H}_{2} \mathrm{SO}_{4}$ was added to each sample mixture. This mixture was

Table 3. Chemical composition $(\mathrm{g} / \mathrm{kg}$ of $\mathrm{DM}$; mean $\pm \mathrm{SD})$ and nutritional content of pasture systems forages (grass and clover) collected weekly throughout lactation, analyzed by near-infrared spectroscopy

\begin{tabular}{lcc}
\hline Item $^{1}$ & Grass & Clover \\
\hline OM & $928.00 \pm 9.31$ & $931.49 \pm 7.18$ \\
OM digestibility & $764.43 \pm 19.34$ & $769.22 \pm 18.97$ \\
CP & $210.90 \pm 23.71$ & $220.67 \pm 14.05$ \\
ADF & $218.89 \pm 16.91$ & $220.67 \pm 14.05$ \\
NDF & $427.62 \pm 23.83$ & $423.46 \pm 18.94$ \\
Ash & $72.00 \pm 9.31$ & $68.51 \pm 7.18$ \\
UFL (/kg of DM) & $0.99 \pm 0.03$ & $1.00 \pm 0.03$ \\
PDIA (/kg of DM) & $41.79 \pm 3.03$ & $44.80 \pm 2.99$ \\
PDIE (/kg of DM) & $100.91 \pm 3.38$ & $104.48 \pm 3.50$ \\
PDIN (/kg of DM) & $135.96 \pm 15.73$ & $151.67 \pm 15.52$ \\
\hline
\end{tabular}

${ }^{1} \mathrm{UFL}=$ unité fourragère lait; PDIA $=$ sum of the feed protein ruminally undegraded and truly digested in the small intestine; PDIE = sum of PDIA and the microbial true protein that is truly digested in the small intestine (PDIM) when energy is limiting; PDIN = sum of PDIA and PDIM when nitrogen is limiting. 
extracted 3 times with $15 \mathrm{~mL}$ of diethyl ether/heptane (1:1), and each time the solution was clarified by centrifugation at $1,500 \times g$ for $5 \mathrm{~min}$ at $20^{\circ} \mathrm{C}$. The collected extracts were pooled and dried at $55^{\circ} \mathrm{C}$ under $\mathrm{N}$ gas.

Methyl Ester Derivatization of Triglycerides. A volume of $4.8 \mathrm{~mL}$ of C19:0 triglycerides $(500 \mathrm{mg} / \mathrm{L}$ ) in heptane was added to $60 \mathrm{mg}$ of the extracted lipid sample after which $200 \mu \mathrm{L}$ of $2 M$ sodium methoxide solution was added and the sample was mixed vigorously for about $30 \mathrm{~s}$. Then, $1 \mathrm{~g}$ of sodium hydrogen sulfate monohydrate (Sigma Aldrich, Dublin, Ireland) was added to the solution and shaken vigorously. After the salt had settled, the upper layer containing the methyl esters was poured into a clean test tube and diluted with $8 \mathrm{~mL}$ of heptane. Fatty acid methyl esters were stored at $-20^{\circ} \mathrm{C}$ before $\mathrm{GC}$ analysis in $2-\mathrm{mL}$ amber vials that were capped with polytetrafluoroethylene/ white silicone septa.

Instrument Conditions for Analysis of FAME. Fatty acid methyl ester analysis was performed on an Agilent 7890B gas chromatograph, equipped with a GC80 autosampler (Agilent Technologies, Little Island, Cork, Ireland) and a flame ionization detector. The column was a Select FAME capillary column $(100 \mathrm{~m}$ $\times 250 \mu \mathrm{m}$ I.D., $0.25 \mu \mathrm{m}$ phase thickness, part number: CP7420, Agilent Technologies). The injector was held at $250^{\circ} \mathrm{C}$ for the entire run and was operated in split mode using a split ratio of $1: 10$, and the injection volume was $1 \mu \mathrm{L}$. The inlet liner was a split gooseneck liner (part no. 8004-0164, Agilent Technologies). The column oven was held at $80^{\circ} \mathrm{C}$ for $8 \mathrm{~min}$ and raised to $200^{\circ} \mathrm{C}$ at $8.5^{\circ} \mathrm{C} / \mathrm{min}$ and held for $55 \mathrm{~min}$. The total run time was $77.12 \mathrm{~min}$. The flame ionization detector was operated at $300^{\circ} \mathrm{C}$. The carrier gas was helium and was held at a constant flow of $1.0 \mathrm{~mL} / \mathrm{min}$. Results were processed using OpenLab CDS Chemstation edition software version Rev.C.01.05 (Agilent Technologies).

Standard curves for FAME analysis along with in-run quality control samples were prepared using an Agilent 7696A Sample Prep Workbench instrument (Agilent Technologies).

Nutritional Indices and FA Ratios. Several FA ratios and nutritional indices of milks from each of the feeding systems are reported. The summation of n-6 (linolelaidic acid, linoleic acid, eicosatrienoic acid, and arachidonic acid), n-3 [ $\alpha$-linolenic acid (ALA)], and n-9 (oleic acid and erucic acid) is reported. Other longer chain n-3 FA including eicosapentaenoic acid (EPA) and docosahexaenoic acid (DHA) have been found in milk at low concentrations, but were not present at quantifiable levels in our analysis. Similar to Benbrook et al. (2013), to more fully reflect variations in levels of health-promoting dairy FA, we have also included total n-3 and CLA, and as Benbrook et al. (2013) described with this in mind, we also include the ratio of n- 6 FA to n-3 + total CLA to fully reflect these variations. The atherogenicity index and thrombogenicity index outlined by Ulbricht and Southgate (1991) are dietary risk indices for cardiovascular disease. The atherogenicity index indicates the relationship between FA with proatherogenic and those with anti-atherogenic properties, showing the inhibition of aggregation of plaque and diminishing the levels of esterified FA, cholesterol, and phospholipids, whereas thrombogenicity index shows the relationship between pro-thrombogenic (saturated) and anti-thrombogenic fatty acids, indicating the tendency to form clots in the blood (Šimat et al., 2015).

Atherogenicity index (AI) and thrombogenicity index (TI) have been calculated as described by Ulbricht and Southgate (1991):

$$
\begin{aligned}
\mathrm{AI}= & \frac{\mathrm{C} 12: 0+(4 \times \mathrm{C} 14: 0)+\mathrm{C} 16: 0}{\mathrm{n}-6 \text { PUFA }+\mathrm{n}-3 \text { PUFA }+ \text { MUFA }}, \\
\mathrm{TI}= & \frac{\mathrm{C} 14: 0+\mathrm{C} 16: 0+\mathrm{C} 18: 0}{(0.5 \times \mathrm{MUFA})+(0.5 \times \mathrm{n}-6 \text { PUFA })} . \\
& +(3 \times \mathrm{n}-3 \text { PUFA })+\left(\frac{\mathrm{n}-3 \text { PUFA }}{\mathrm{n}-6 \text { PUFA }}\right)
\end{aligned}
$$

Desaturase index (DI) was calculated as described by Kay et al. (2005):

$$
\frac{\left(\text { product of } \Delta^{9} \text {-desaturase }\right)}{\left(\begin{array}{l}
\text { product of } \Delta^{9} \text {-desaturase }+ \\
\text { substrate of } \Delta^{9} \text {-desaturase }
\end{array}\right)}
$$

Therefore,

$$
\mathrm{DI}=\frac{(\mathrm{C} 14: 1+\mathrm{C} 16: 1+\mathrm{C} 18: 1)}{\left[\begin{array}{l}
(\mathrm{C} 14: 0+\mathrm{C} 16: 0+\mathrm{C} 18: 0) \\
+(\mathrm{C} 14: 1+\mathrm{C} 16: 1+\mathrm{C} 18: 1)
\end{array}\right]} .
$$

\section{Statistical Analysis}

Statistical analysis was performed using SPSS v18.0 (IBM Statistics Inc., Armonk, NY). A between- and within-subjects repeated measures ANOVA with post hoc Tukey test was used to compare chemical compositions and FA content of milks from herds on different feeding systems (TMR, GRS, and CLV) throughout lactation (March to October). $P$-values $<0.05$ were considered significant. The strength of statistically 
significant results are also reported as the partial eta ${ }^{2}$ effect size $\left(\eta^{2}\right)$ where effect sizes are small $\left(0.01 \leq \eta^{2}\right.$ $<0.06)$, medium $\left(0.06 \leq \eta^{2}<0.14\right)$, and large $\left(\eta^{2} \geq\right.$ 0.14). Principal component analysis of milk FA averages data set was performed using The Unscrambler $\mathrm{X}$ multivariate analysis program, v10.3 (CAMO ASA, Trondheim, Norway). Analysis of milks was performed on a weekly basis in duplicate throughout lactation; monthly and lactation figures reported below are the mean and standard deviation of all weeks within that period.

\section{RESULTS}

\section{Milk Chemical Composition}

The results of this study demonstrate that the feeding system had a significant effect $(P \leq 0.05)$ on daily milk yield of cows throughout lactation. The TMR cows had the highest daily milk yields, which were significantly higher than the GRS and CLV systems $(P<0.001)$, and daily milk yield of CLV cows was also significantly higher than GRS cows $(P<0.001$; see Table 4$)$. Average weekly, monthly, and total lactation milk chemical composition for the TMR, GRS, and CLV feeding systems are shown in Figures 1 and 2 and Table 5 .

Total lactation average milk solids content from cows on the GRS system was significantly higher than that of TMR $(P<0.001)$ and CLV $(P<0.001)$ systems. There was no significant difference in average lactation TS contents between TMR and CLV milk (Figure 2A). Average TS content for early, mid, and late lactation were $($ mean $\pm \mathrm{SD}) 13.06 \pm 0.25,13.02 \pm 0.19$, and $14.00 \pm 0.26 \%$ for TMR, $13.60 \pm 0.23,13.56 \pm 0.20$, and $14.58 \pm 0.41 \%$ for GRS and $13.14 \pm 0.15,13.21 \pm$ 0.18 , and $13.99 \pm 0.36 \%$ for CLV systems, respectively. Maximum solids contents were recorded in September and minimum contents were observed during early lactation (March/April) for each diet (Figure 1A).

The cows from the GRS feeding system produced milk with significantly higher $(P<0.001)$ total lactation average milk fat content than that of TMR and
CLV systems (Figure 2B). There was no significant difference in total lactation fat contents between TMR and CLV milk. Average milk fat content for early, mid, and late lactation were (mean $\pm \mathrm{SD}$ ) $4.23 \pm 0.18,4.24$ \pm 0.18 , and $4.65 \pm 0.13 \%$ for TMR, $4.56 \pm 0.26,4.46 \pm$ 0.19 , and $4.90 \pm 0.29 \%$ for GRS and $4.04 \pm 0.18,4.21$ \pm 0.17 , and $4.57 \pm 0.24 \%$ for CLV, respectively. Maximum fat concentrations were recorded in October and minimum fat concentrations were observed in March/ April for each diet (Figure 1B).

The cows in both the GRS and CLV feeding systems produced milk with significantly higher protein concentration than that of cows on the TMR system $(P$ $<0.001$; Figure 2D and 2E). No significant difference was found in the average lactation milk TP contents between GRS and CLV systems. However, on a \% of total protein basis, GRS-derived milks had significantly higher lactation average $\%$ TP of total protein content $(94.59 \pm 0.82 \%)$ than TMR $(P=0.003 ; 94.02 \pm 0.72 \%)$ and $\operatorname{CLV}(P<0.001 ; 93.65 \pm 1.16 \%)$, which was also significantly greater than TMR $(P=0.036$; Figure $2 \mathrm{~F})$. Crude and TP contents also varied throughout lactation, whereby average $\mathrm{CP}$ contents for early, mid, and late lactation were (mean \pm SD) $3.11 \pm 0.09,3.27 \pm$ 0.11 , and $3.68 \pm 0.10 \%$ for TMR; $3.33 \pm 0.09,3.50$ \pm 0.18 , and $4.02 \pm 0.17 \%$ for GRS; and $3.31 \pm 0.11$, $3.45 \pm 0.10$, and $3.84 \pm 0.21 \%$ for CLV, respectively. Maximum milk protein concentrations were recorded in October and minimum protein concentrations were observed in March/April for each diet (Figure 1D). Milk casein content from the TMR system was lower than both GRS $(P=0.008)$ and CLV systems. However, no significant difference was found in casein contents of GRS and CLV milks. Casein and whey contents increased throughout lactation in each system. Maximum milk casein and whey concentrations were recorded during late-lactation in October and minimum concentrations for each were observed in March/April for each diet.

Lactose concentration did not differ $(P>0.05)$ between feeding systems throughout lactation, but did vary by time, particularly in late lactation. The lactose

Table 4. Mean daily milk yield data of individual cows from TMR, grass, and clover feeding systems throughout the duration of the lactation trial and live weight of cows at the end of the trial in October

\begin{tabular}{lrrrrr}
\hline & \multicolumn{3}{c}{ Feeding system } & & \\
\cline { 2 - 4 } Item & TMR & Grass & Clover & \multirow{2}{*}{ SE } & P-value \\
\hline Milk yield (L/d) & 27.71 & 20.98 & 24.59 & 0.14 & $<0.001$ \\
Milk solids (kg/d) & 2.24 & 1.78 & 1.99 & 0.01 & $<0.001$ \\
Protein $(\mathrm{kg} / \mathrm{d})$ & 0.94 & 0.76 & 0.87 & 0.01 & $<0.001$ \\
Fat $(\mathrm{kg} / \mathrm{d})$ & 1.31 & 1.02 & 1.12 & 0.03 & $<0.001$ \\
Lactose $(\mathrm{kg} / \mathrm{d})$ & 1.32 & 1.01 & 1.18 & 0.01 & 0.716 \\
Live weight $(\mathrm{kg})$ & 591.51 & 532.11 & 550.45 & 13.15 & $<0.001$ \\
\hline
\end{tabular}



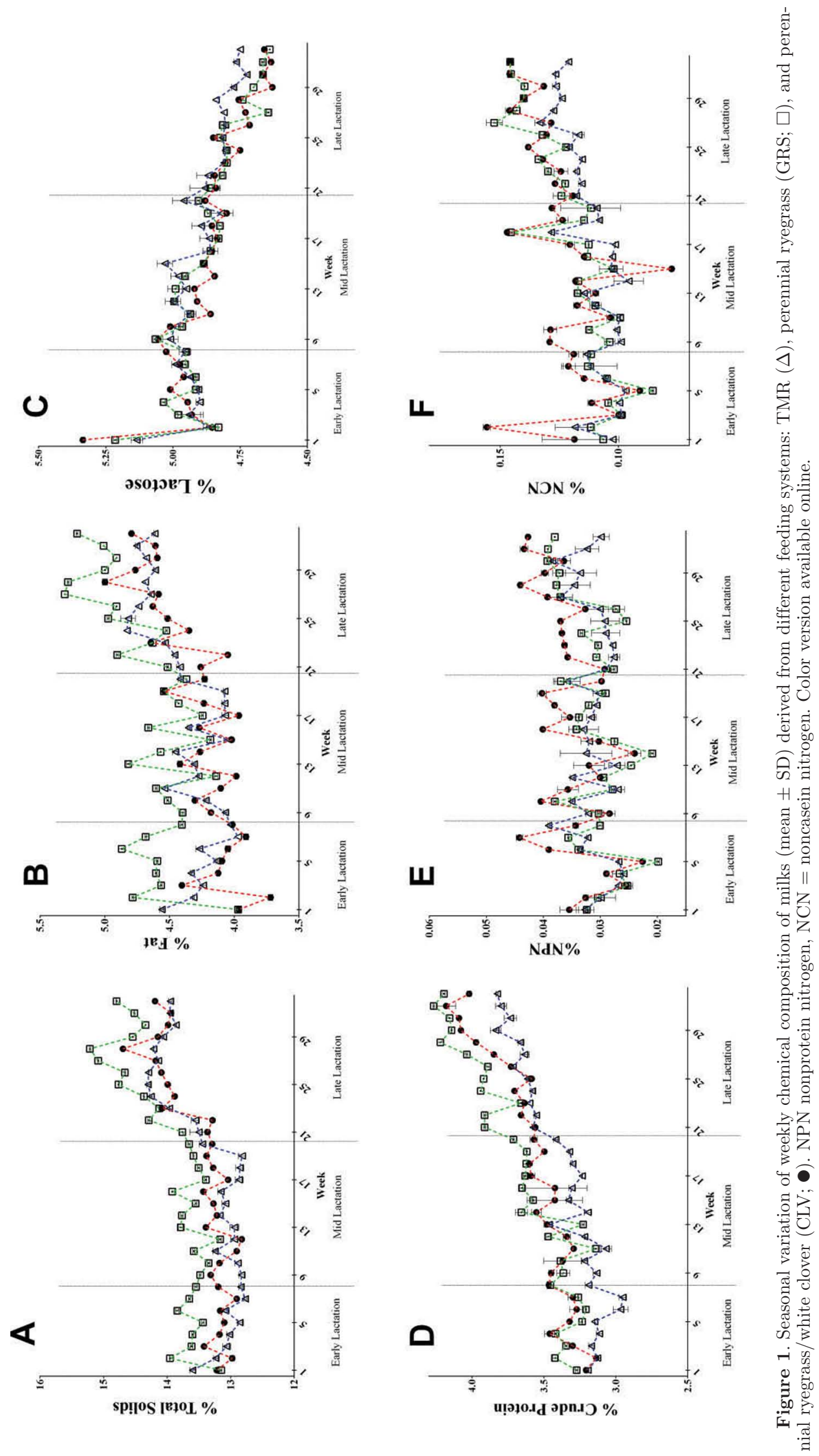

Journal of Dairy Science Vol. 99 No. 12, 2016 

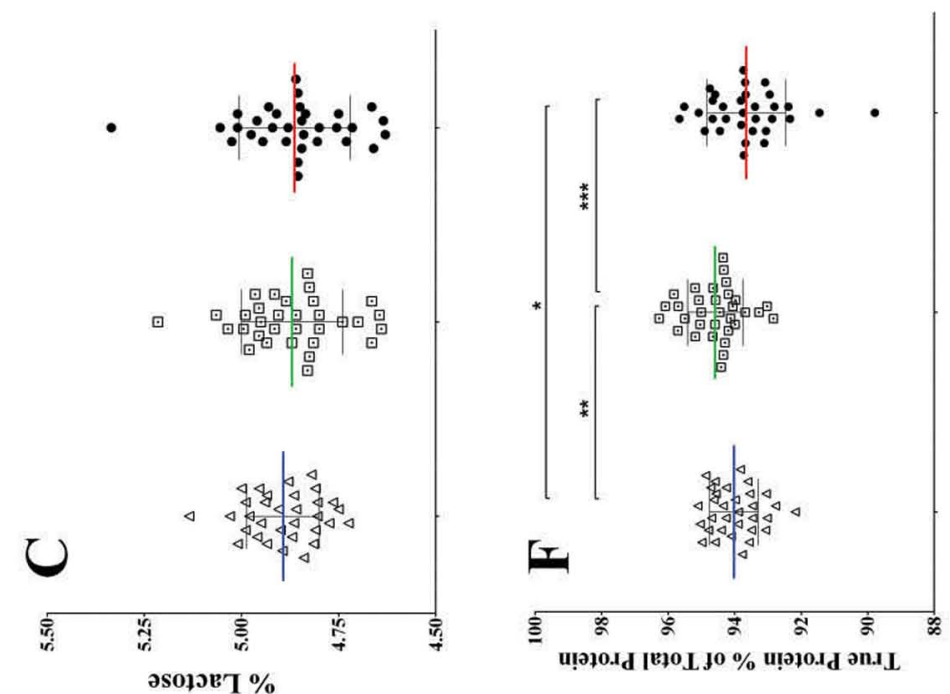

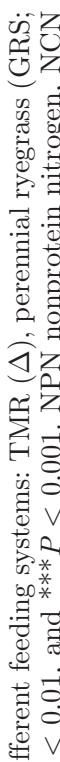
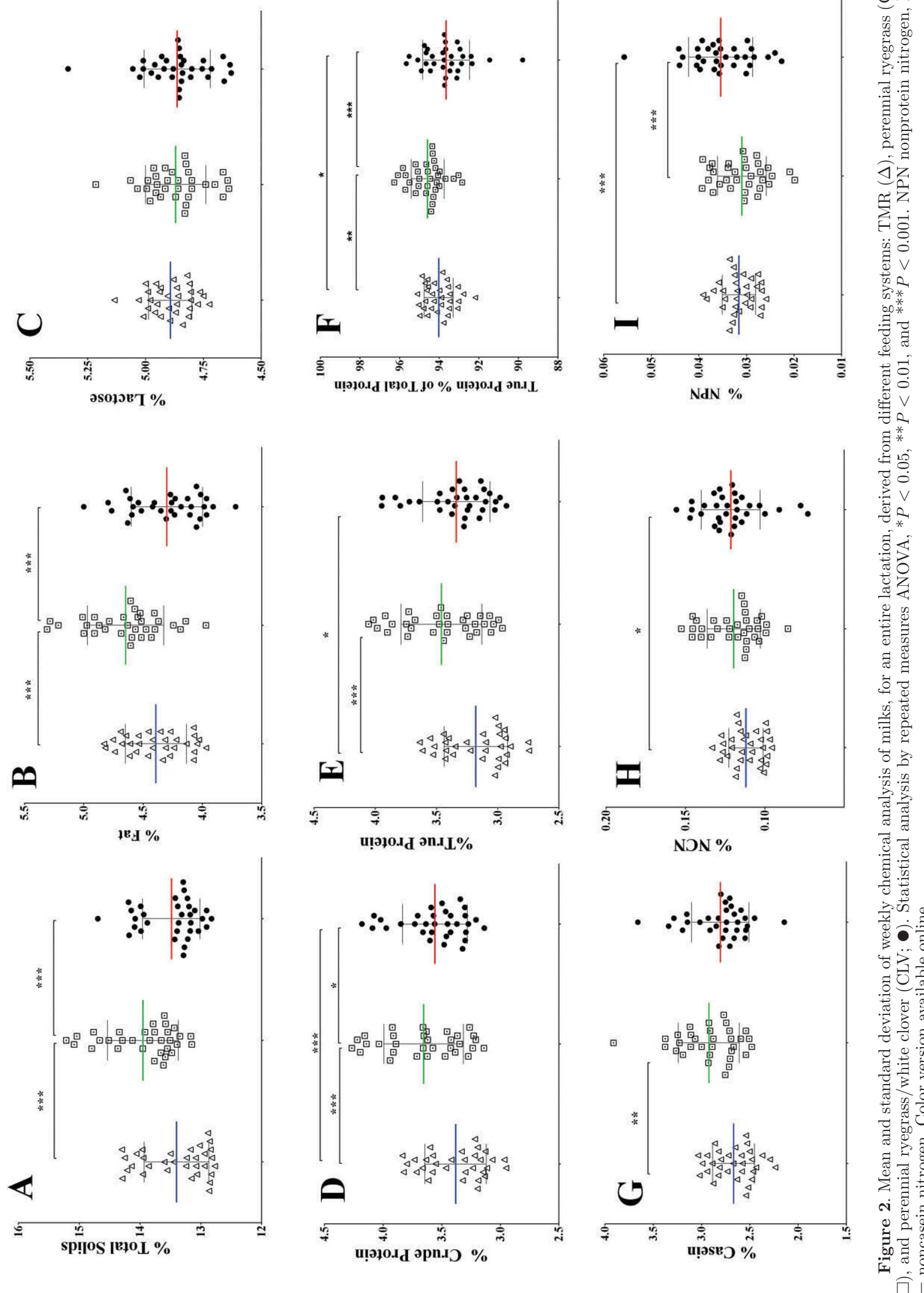
FEEDING SYSTEM AND RAW MILK COMPOSITION

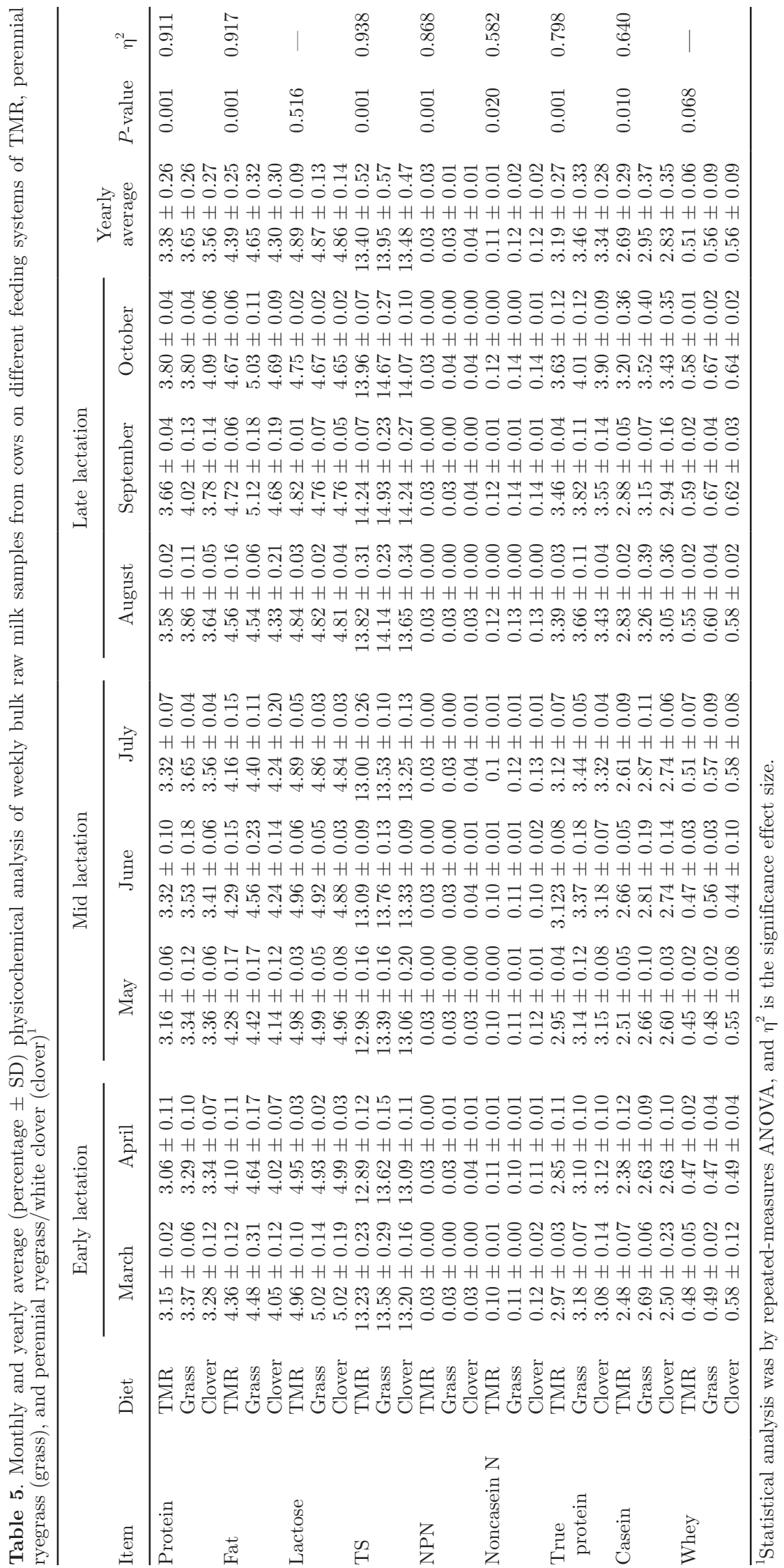


content of milks remained relatively stable in early and mid-lactation at $4.95 \pm 0.08$ and $4.94 \pm 0.06 \%$ for TMR, $4.97 \pm 0.11$ and $4.92 \pm 0.07 \%$ for GRS, and 5.00 \pm 0.13 and $4.84 \pm 0.07 \%$ for CLV, respectively. There was a reduction in milk lactose concentrations in late lactation for all 3 systems; milk lactose concentrations in October were $4.75 \pm 0.02 \%, 4.67 \pm 0.02 \%$, and 4.65 $\pm 0.02 \%$ for TMR, GRS, and CLV, respectively. The highest lactose concentrations were recorded during the early lactation period in March and the lowest figures were recorded in October (Figure 1C).

No significant difference was found in average yearly NPN concentration between TMR and GRS milk. The NPN concentration of CLV milk was significantly higher $(P<0.001)$ than that of TMR and GRS milk samples for yearly production (Figure 2I). Noncasein N content was highest in CLV milk which was significantly higher $(P=0.017)$ than that of TMR milk (Figure $2 \mathrm{H})$.

\section{Milk FA Composition}

A total of 27 FA triglycerides were quantified (g/100 $\mathrm{g}$ of milk fat) from raw milks each week throughout lactation by GC-flame ionization detector. Overall, 16 of these FA varied significantly $(P \leq 0.05)$ between the different feeding systems. A list of milk FA contents (mean $\pm \mathrm{SD}$ ) during early (March-April), mid (MayJuly), and late lactation (August-October) is displayed in Table 6.

The most abundant FA in milk from each feeding system throughout lactation were palmitic acid (C16:0) and oleic acid (C18:1n-9 cis). Average palmitic acid content for the year was highest in TMR at $24.39 \pm$ $2.45 \mathrm{~g} / 100 \mathrm{~g}$ of milk fat, which was significantly higher than GRS at $20.78 \pm 2.65 \mathrm{~g} / 100 \mathrm{~g}$ of milk fat $(P=$ $0.008)$ and CLV at $20.17 \pm 2.76 \mathrm{~g} / 100 \mathrm{~g}$ of milk fat $(P$ $=0.003)$. No significant difference was found between the palmitic acid content of GRS and CLV milk samples. Total mixed ration milk had the highest average oleic acid content for lactation at $14.59 \pm 2.83 \mathrm{~g} / 100$ $\mathrm{g}$ of milk fat, which was not significantly higher than GRS or CLV at $13.99 \pm 3.02$ and $13.23 \pm 2.46 \mathrm{~g} / 100 \mathrm{~g}$ of milk fat, respectively.

Among SFA, significant differences $(P \leq 0.05)$ between feeding systems were recorded for undecanoic acid (C11:0), tridecanoic acid (C13:0), pentadecanoic acid (C15:0), palmitic acid (C16:0), heptadecanoic acid (C17:0), behenic acid (C22:0), and tricosanoic acid (C23:0). Undecanoic acid was significantly lower in TMR at $0.04 \pm 0.02$ than GRS $(P<0.001)$ at $0.06 \pm$ 0.03 and $\operatorname{CLV}(P=0.012)$ at $0.05 \pm 0.02 \mathrm{~g} / 100 \mathrm{~g}$ of milk fat for the year. Tridecanoic acid was lower in TMR, than that of GRS $(P=0.007)$ and CLV milk with average concentrations of $0.07 \pm 0.02,0.08 \pm 0.03$, and 0.08 $\pm 0.02 \mathrm{~g} / 100 \mathrm{~g}$ of milk fat, respectively. Pentadecanoic acid was lower in TMR than that of GRS $(P=0.003)$ and CLV $(P=0.011)$ milk with average concentrations of $0.78 \pm 0.16,0.95 \pm 0.21$, and $0.92 \pm 0.12 \mathrm{~g} / 100 \mathrm{~g}$ of milk fat, respectively. Heptadecanoic acid content was lower in TMR milk than in GRS $(P=0.009)$ and CLV $(P=0.05)$ milk with average concentrations of $0.43 \pm$ $0.08,0.49 \pm 0.09$, and $0.47 \pm 0.07 \mathrm{~g} / 100 \mathrm{~g}$ of milk fat, respectively. Behenic acid was present but not quantified in GC chromatograms during the first month of this study due to levels being too low to quantify. Total lactation average TMR behenic acid concentration was $0.10 \pm 0.06 \mathrm{~g} / 100 \mathrm{~g}$ of milk fat, which was greater $(P$ $<0.001)$ than GRS and CLV milk, which had little or no behenic acid with concentrations of $0.00 \pm 0.01$ and $0.01 \pm 0.02 \mathrm{~g} / 100 \mathrm{~g}$ of milk fat, respectively. The GRS and CLV milks had a greater concentration of tricosanoic acid $(0.04 \pm 0.03$ and $0.05 \pm 0.03 \mathrm{~g} / 100 \mathrm{~g}$ of milk fat, respectively) throughout lactation than TMR $(P<$ 0.001), which was devoid of FA with a concentration of $0.00 \pm 0.01 \mathrm{~g} / 100 \mathrm{~g}$ of milk fat. Tricosanoic acid, also, was present but not quantified in GC chromatograms during the first month of this study due to levels being too low to quantify.

Among MUFA eicosenoic acid (C20:1) and erucic acid varied significantly $(P<0.05)$ between diets. Eicosanoic acid was lowest $(P<0.001)$ in TMR at 0.27 $\pm 0.05 \mathrm{~g} / 100 \mathrm{~g}$ of milk fat and CLV was also greater than GRS $(P<0.001)$ with concentrations of $0.68 \pm$ 0.10 and $0.53 \pm 0.09 \mathrm{~g} / 100 \mathrm{~g}$ of milk fat, respectively. Erucic acid content was highest $(P<0.001)$ in TMR milk samples.

Among the PUFA, linolelaidic acid (C18:2n-6 trans), linoleic acid (C18:2n-6 cis), $\alpha$-linolenic acid (C18:3n-3), $\gamma$-linolenic acid (C18:3n-6 cis), C18:2 CLA (cis-9,trans-11), CLA (cis-10,trans-12), and arachidonic acid $(\mathrm{C} 20: 4 \mathrm{n}-6)$ varied significantly $(P<0.05)$ between feeding systems. Linolelaidic acid was highest in CLV and GRS milks with concentrations of $0.36 \pm 0.04$ and $0.33 \pm 0.06 \mathrm{~g} / 100 \mathrm{~g}$ of milk fat, which were 2.5 times greater than TMR concentration $(P<0.001)$ of 0.15 $\pm 0.07 \mathrm{~g} / 100 \mathrm{~g}$ of milk fat. Linoleic acid was highest in TMR with concentrations of $1.31 \pm 0.28 \mathrm{~g} / 100$ $\mathrm{g}$ of milk fat, almost 2-fold higher content than that of GRS and CLV concentrations $(P<0.001), 0.55 \pm$ 0.21 and $0.64 \pm 0.17 \mathrm{~g} / 100 \mathrm{~g}$ of milk fat, respectively. $\gamma$-Linolenic acid was highest in TMR at $0.04 \pm 0.01$ $\mathrm{g} / 100 \mathrm{~g}$ of milk fat, which was significantly higher $(P$ $<0.001)$ than GRS and CLV's $0.03 \pm 0.01$ and $0.03 \pm$ $0.01 \mathrm{~g} / 100 \mathrm{~g}$ of milk fat, respectively. Pasture feeding system resulted in significantly $(P<0.001)$ higher concentrations of $\alpha$-linolenic acid than that of TMR. The biologically active isomer of CLA $\mathrm{A}_{\text {cis-9trans-11 }}$ was present at highest concentrations in GRS and CLV at $1.44 \pm$ 
0.37 and $1.32 \pm 0.25 \mathrm{~g} / 100 \mathrm{~g}$ of milk fat, respectively, greater than 2 -fold higher $(P<0.001)$ than the average TMR CLA cis-9,trans-11 content of $0.58 \pm 0.15 \mathrm{~g} / 100$ $\mathrm{g}$ of milk fat. Total mixed ration had the highest CLA cis-10,trans-12 content of $0.09 \pm 0.02$. Arachidonic acid was absent in TMR throughout lactation but present in GRS and CLV milks at concentrations of $0.05 \pm$ 0.03 and $0.06 \pm 0.02 \mathrm{~g} / 100 \mathrm{~g}$ of milk fat, respectively $(P<0.001)$. Pasture-derived milks had significantly higher n-3 FA (n-3) content than that of TMR $(P=$ 0.003), whereas TMR milk had a significantly higher concentration of n-6 FA (n-6) than GRS and CLV. The CLV n-6 content was also significantly higher than that of GRS $(P=0.045)$. As a result of this, the ratio of n-6:(n-3+CLA) was significantly lower $(P<0.001)$ in pasture-derived milk than in TMR milk. The feeding system had a significant effect on the desaturase index, with increased desaturase activity associated with GRS-derived milks over TMR $(P=0.026)$. Although there was no significant effect of feeding system on the atherogenicity index of milks, there was a significant effect of feeding system on the thrombogenic index, where TMR scores were significantly higher than that of pasture-derived milks $(P<0.01)$.

\section{Principal Component Analysis}

The similarity plot defined by principal components PC-1 and PC-2 showed a clear discrimination of samples according to both feeding system and stage of lactation (Figure 3). All samples from early lactation are located on the positive side of the plot, whereas mid and late lactation samples did not appear to cluster based on season but are very clearly separated according to feeding system. All TMR samples clustered on the positive side of the plot; however, the majority of GRS and CLV samples are located in the negative section. Early lactation samples were characterized by oleic acid and stearic acid, whereas mid and late lactation TMR samples are characterized by behenic acid, erucic acid, palmitic acid, $\gamma$-linoleic, and linoleic acid. In contrast, however, mid and late lactation GRS and CLV samples are characterized closely by pentadecanoic acid, tridecanoic acid, tricosanoic acid, linolenic acid, CLA (C18:2 cis-9,trans-11), arachidonic acid, undecanoic acid, and linolelaidic acid content, which is in agreement with Table 6 .

\section{DISCUSSION}

Several studies in the past have reported that TMR and white clover diets are associated with increased milk yields from the cow when compared with pastureonly diets. Studies investigating the use of TMR feeding systems have reported an increased DMI, and due to the high protein and dietary fat nature of a TMR diet, increased net energy intake has resulted in significantly greater milk yields than that of a pasture-based system (Kelly et al., 1998; Kolver et al., 2000; Bargo et al., 2002; O'Neill et al., 2011; Kennedy et al., 2015). In contrast, white clover perennial ryegrass has a lower resistance to chewing than other grasses with increased daily DMI (10-35\%) being reported (Caradus et al., 1996). This, coupled with its high nutritive and feeding value, higher digestible protein, and faster rate of passage through the rumen, means white clover feeding systems have resulted in increased milk yield, compared with perennial rye pastures not containing any clover (Ulyatt, 1981; Minson, 1990; Harris et al., 1997). With this in mind, the present study investigated the effects on milk composition from feeding cows a diet of TMR, perennial ryegrass only or perennial ryegrass/white clover throughout an entire lactation. Our data revealed similar trends for milk yield to those mentioned above (Table 4).

Seasonal variations in milk composition of pasturebased systems have been well described in the past. Milk composition from each feeding system in this study all followed similar lactation trends to each other, which are in agreement with those of previous studies conducted in both Ireland and New Zealand (Lucey, 1996; Auldist et al., 1998; Figure 1). Concentrations of TS and macronutrient components of milks (e.g., fat protein, casein, whey) were lowest in early lactation and increased as lactation progressed. This trend is likely due to a concentrating effect as a result of reduced milk yield as cows progressed from the mid to late stage of lactation (Auldist et al., 1998). The GRS milk had significantly higher yearly average TS content than that of TMR and CLV milks, which can be attributed to the significantly higher fat and protein contents of GRS; indeed, among milk composition, fat and protein are the 2 components most subjected to change due to feeding system (Santos, 2002).

The GRS milk had significantly higher fat content than TMR and CLV feeding systems $(4.65,4.39$, and $4.30 \%$ fat, respectively), which is consistent with past studies where milk fat percentage from cows grazing pasture was increased compared with that of a TMR feeding system (Kelly et al., 1998; Kolver et al., 2000; Kay et al., 2005). Reynolds (2006) reported that grains such as maize used in TMR diets can provide a high proportion of starch for digestion in the small intestine leading to an increase in milk yield and a decrease in milk fat concentration. The CLV diet resulted in a reduced milk fat content, which concurs with a study by Harris et al. (1997) where increased proportions of white clover in the diet increased daily milk yield and reduced 


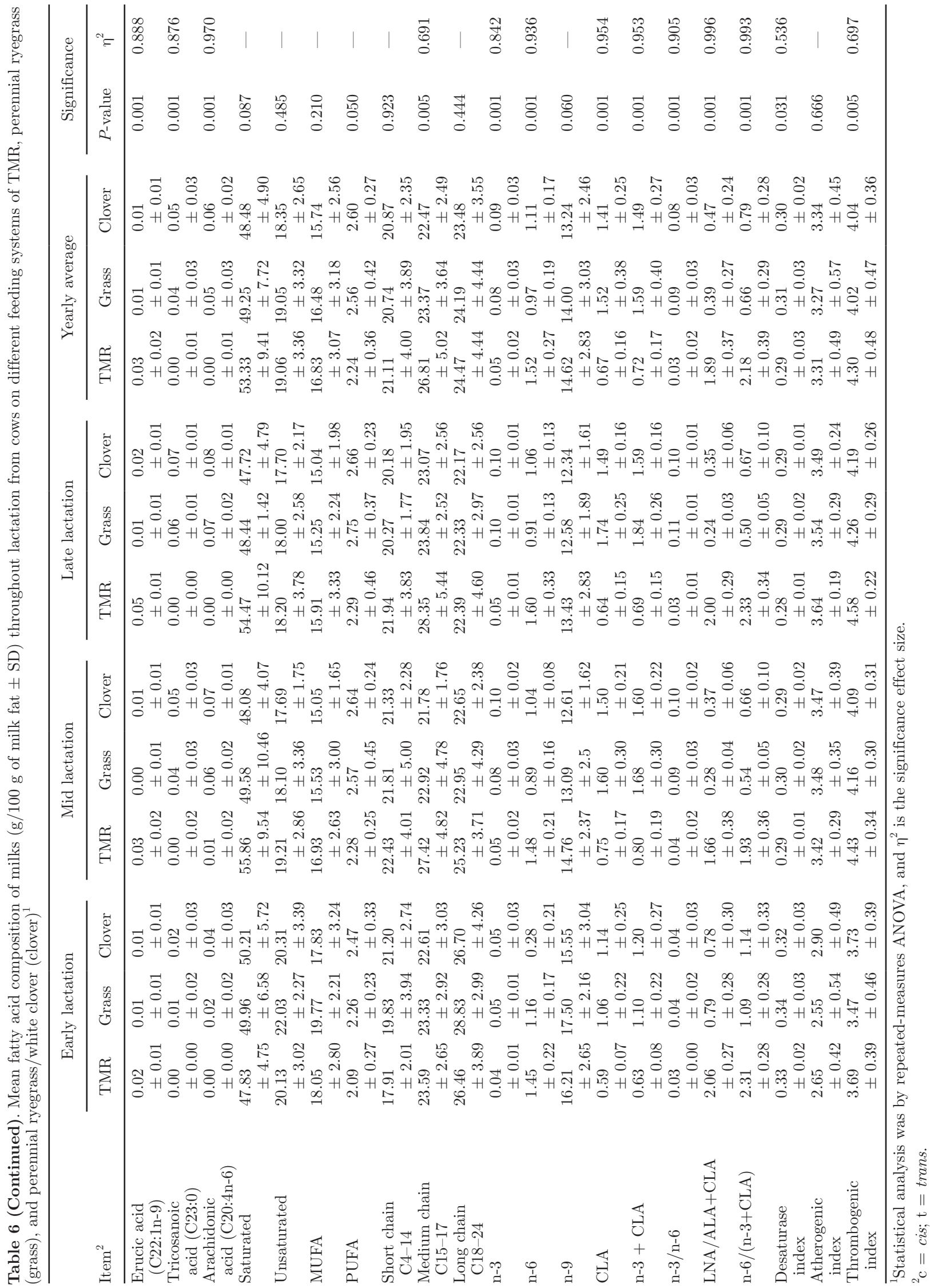




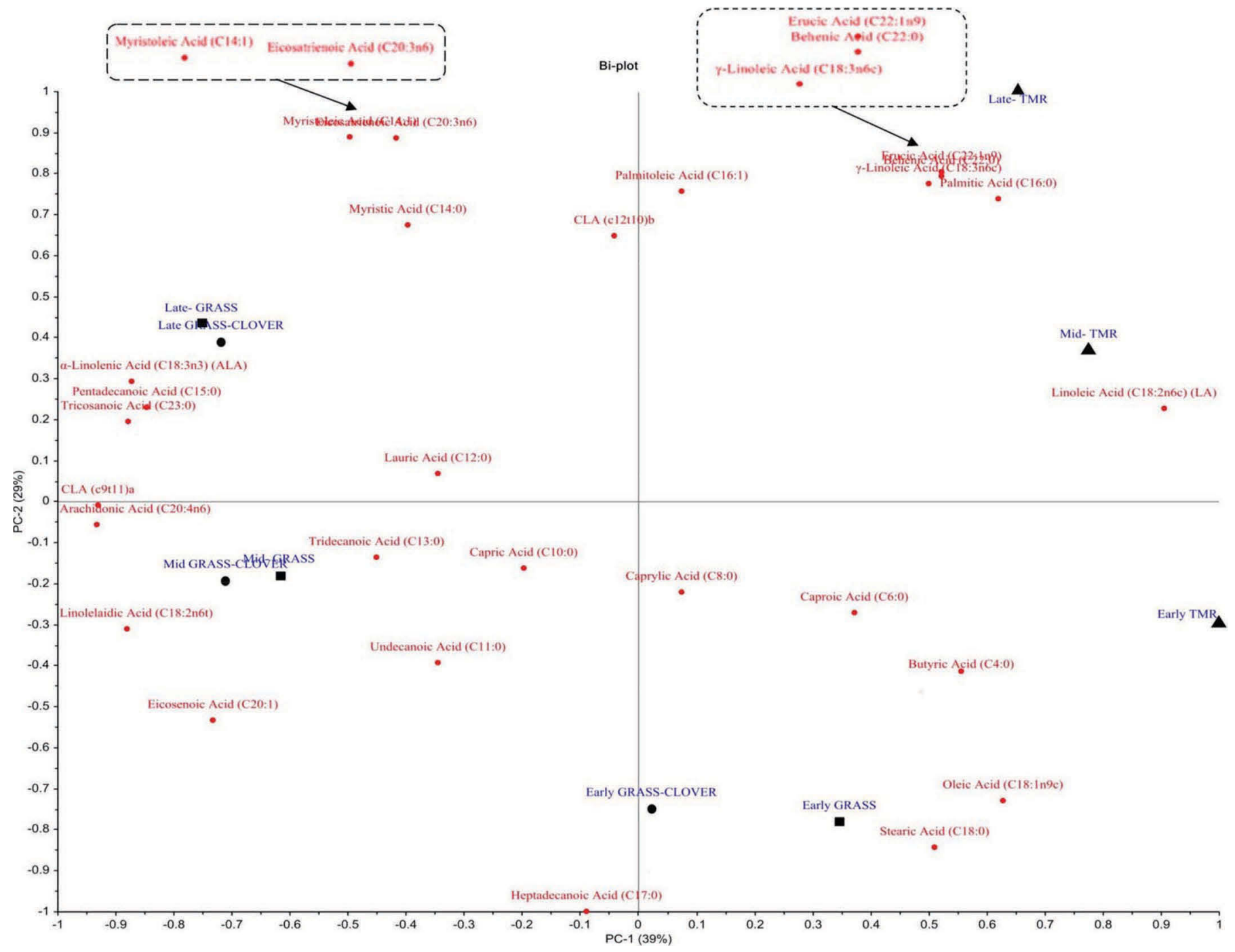

Figure 3. Principal coordinate analysis plot of mean raw milk FAME results throughout lactation, indicating clear separation of milks from pasture and TMR feeding systems [TMR $(\boldsymbol{\Lambda})$, perennial ryegrass $(\boldsymbol{\square})$, perennial ryegrass/white clover $(\bullet)]$, and stage of lactation (early, mid, and late). $\mathrm{c}=c i s ; \mathrm{t}=$ trans. Color version available online.

the fat content of milk compared with cows consuming no clover. Similar studies in the past have found that use of a TMR feeding system can produce milk with higher fat contents (Dhiman et al., 1999; Couvreur et al., 2006). Feeding of TMR diets high in UFA has been linked with a reduction in milk fat content as UFA are toxic to many rumen bacteria, particularly those responsible for fiber degradation, resulting in reduced activity of acetyl CoA carboxylase enzyme and de novo synthesis (Palmquist and Jenkins, 1980; Piperova et al., 1998).

Pasture-based diets (GRS and CLV) had significantly higher yearly average protein content than that of the TMR diet (3.65, 3.56, and $3.38 \%$ protein, respectively), and possibly, more importantly, from a manufacturing perspective, TP and casein content also followed this trend. Although Harris et al. (1998) found no significant difference in $\mathrm{CP}$ contents of milks from pasture with and without inclusion of white clover, there was a significant difference in the CP contents of GRS and CLV diets here, which could be attributed to increased milk yield associated with CLV system. Increased protein content of pasture milk over TMR milk has also been seen by Couvreur et al. (2006) who reported a linear increase in milk protein content with increasing pasture content of the cows' diet. Couvreur et al. (2006) attributed the increase in protein content to a modification of energy provided to the udder by an increase in propionic acid supplied to the rumen from GRS diets. Dhiman et al. (1999) and Schroeder et al. (2003), however, have reported increased protein contents in milks derived from increased protein and energy intake with 
TMR feeding systems. In contrast, studies have shown that protein content may be negatively influenced by a high intake of dietary fat (DePeters and Ferguson, 1992).

The GRS milk was shown to have significantly higher quality protein with highest TP content of total protein (Figure 2F). Significant differences in the TP and casein contents of milks could be of concern to milk manufacturers as previous studies have attributed improved cheese-making properties and rennet coagulation characteristics to milk with increased protein and casein concentration (O'Brien et al., 1999; Amenu et al., 2006). It has been reported that a $0.1 \%$ reduction in total casein concentration can cause a reduction in cheddar cheese yield potential by $0.5 \mathrm{~kg} / 100 \mathrm{~kg}$ of milk (Guinee et al., 2001), resulting in major losses for cheese manufacturers (Amenu et al., 2006). The CLVderived milk had a higher NPN concentration $(0.04 \%)$ than that of GRS or TMR, which were the same (0.03 vs. $0.03 \% \mathrm{NPN}$ ) and CLV NCN concentrations were significantly higher than those of TMR milk (0.124 vs. $0.112 \%$ NCN). Such NPN and NCN results are similar to those of Harris et al. (1998) who reported that increased clover proportions in the diet resulted in higher urea concentrations, which can account for up to $48 \%$ of NPN content (Wolfschoon-Pombo and Klostermeyer, 1981). Increased proportions of NPN and NCN could be of concern to dairy manufacturers whose typical payment scheme is on a CP basis, with increased NPN and NCN resulting in poorer quality protein and potential reduction in product yields.

Milk fat is primarily composed of 2 major fractions: long-chain FA (50-70\%) and short-chain FA (30-50\%). Long-chain FA are typically derived from the dietary system; short-chain FA, however, are synthesized de novo by the mammary gland, utilizing precursors such as acetate and butyrate (Santos, 2002). No significant difference was found in total SFA content in each milk; pasture-derived milks had insignificantly lower amounts of SFA compared with TMR milk, which correlates with a similar study by Baltušnikienè et al. (2008) comparing milk FA content from TMR and pasture diets. Lower SFA content would be a beneficial attribute for human health as consumption of saturated fat has been associated with several human diseases, especially cardiac problems in the past (Pfeuffer and Schrezenmeir, 2000). However, there is increasing evidence available that dietary SFA, in the context of dairy foods, have a neutral or inverse association with cardiovascular disease (Siri-Tarino et al., 2015). The pasture diets had significantly higher concentrations of undecanoic acid and pentadecaoic acid similar to results reported by Adler et al. (2013) who compared organic versus TMR farming systems effects on milk. Baltušnikienè et al.
(2008) reported that cows consuming a TMR diet produced milk with higher levels of palmitic acid, which was also observed in this study. Such results coupled with increased amounts of total medium-chain FA indicate an association between pasture diets and increased de novo synthesis of FA occurring in the mammary gland. Increased levels of linolelaidic and $\alpha$-linoleic acid in pasture-derived milks and increased linoleic acid content in TMR milks was also observed by Couvreur et al. (2006) when examining the effects of $100 \%$ corn silage diets versus a $100 \%$ grass diet on milk composition. Two processes that contribute to the development of ischemic heart disease include atherosclerosis and thrombosis, and the occurrence of both of these can be attributed to consumption of dietary fats (Fehily et al., 1994). Alterations in the FA of milks between feeding systems resulted in TMR-derived milks having significantly higher thrombogenicity indices than those of pasture-derived milks.

The n- 6 and n-3 PUFA have been described as precursors to eicosanoids, which are potent lipid-mediating signaling molecules that play a role in regulation of inflammation. In general, n-6-derived eicosanoids are pro-inflammatory whereas n-3-derived eicosanoids are anti-inflammatory (Patterson et al., 2012). The ratio of n-3 to n-6 FA in dietary products has received much attention in recent years and evidence is increasing that the dietary balance of n-3 and n- 6 FA is perhaps as important as the dietary proportions of SFA, MUFA, PUFA, and total fat (Benbrook et al., 2013). The nutritionally optimum intake ratio of n- 6 to n-3 FA for humans has been reported to be near 1-4:1; however, in recent years the Western diet has resulted in significant increases in n-6 FA to undesirable levels of as high as 15:1. Coinciding with this increased intake of n-6 FA in the Western diet are increases in inflammatory related diseases, see review by Patterson et al. (2012). Milks derived from TMR had 27\% higher n-6 FA content than that of pasture-derived milks, whereas the n-3 FA content of pasture-derived milks was $37 \%$ higher than that of TMR-derived milk. These data corroborate results reported by Benbrook et al. (2013), who performed a nationwide study of FA content of milks from conventional and organic dairy farms in the United States. The beneficial modulation of the level of n-6 and n-3 FA content of milks from pasture-based cows could be beneficial for combating this negative trend of high n-6 and low n-3 FA intake in developed societies (Benbrook et al., 2013).

The bioactive isomer CLA has been shown to exert potent physiological functions such as antihypertensive, antiobesity, antidiabetic, and anti-carcinogenic properties (Koba and Yanagita, 2014). Conjugated linoleic acid is formed in the rumen as an intermediate in the 
biohydrogenation pathway of linoleic acid to stearic acid by Butyrivibrio fibrisolvens (Kelly et al., 1998; Baltušnikienè et al., 2008; Koba and Yanagita, 2014). Many studies in the past have reported the positive linear response of CLA concentration in cow milk to intake of fresh pasture (Stanton et al., 1997; Kelly et al., 1998; Dhiman et al., 1999; White et al., 2001; Slots et al., 2009). We revealed that pasture-fed cows in the current study produced a greater than 2-fold concentration of CLA cis-9,trans-11 than that of TMR (1.38 vs. $0.58 \mathrm{~g} / 100 \mathrm{~g}$ of milk fat, respectively). This result is similar to that reported in past studies (Kelly et al., 1998; White et al., 2001; Couvreur et al., 2006) and is a much higher increase than that reported by Baltušnikienè et al. (2008). Milk fat CLA is affected by intake of UFA. In this respect, fresh-pasture-associated increases in milk CLA content have been attributed to increased $\alpha$-linolenic acid content in grasses, which is extensively biohydrogenated in the rumen (Harstad et al., 2010). The GRS milk also had a higher desaturase index than TMR milk, indicating increased activity of stearoyl CoA desaturase, which is involved in CLA production (Medrano et al., 1999); this result is also in agreement with results by Lock and Garnsworthy (2003), who also suggested that fresh grass promotes the synthesis of CLA through an increase in $\Delta^{9}$-desaturase activity. Data from the current study revealed greater variation in the CLA content of GRS and CLV samples throughout lactation, than that of TMR (SD of 0.15, 0.37 , and $0.25 \mathrm{~g} / 100 \mathrm{~g}$ of milk fat, respectively). Similar variations in CLA content have been reported in the past by Kelly et al. (1998).

Principal component analysis of average milks FA contents showed clear separation throughout the entire lactation between TMR-fed and pasture-based milk. Overall, this analysis shows that the FA composition of milks from TMR diets and pasture-based diets was quite distinct, whereas the GRS and CLV pasture diets were much less differentiated. Similarly, early lactation milks were very different to mid and late lactation samples, however, little distinction was found between mid and late lactation samples within TMR and pasture feeding systems, indicating that FA profiling could be used as a tool for verification of pasture-derived feeding systems over TMR systems. This result is in agreement with results reported by Capuano et al. (2014), which concluded that FA profiling may be used for the verification of fresh grass feeding of cows.

\section{CONCLUSIONS}

The novelty of this study was the real-time comparison of 3 distinct feeding systems widely practiced throughout the world on dairy cows over a full lacta- tion period. Observed variations in milk composition could be linked to both stage of lactation and feeding system used. In conclusion, pasture-based feeding systems have been shown to produce milk with increased concentrations of fat and protein. Moreover, the GRS feeding systems produced milks with better quality protein with increased TP concentrations. The use of a TMR feeding system resulted in significant decreases in protein, fat, casein, and whey concentrations. The inclusion of CLV appeared to produce milk with compositional concentrations more comparable to that of GRS. The feeding system used also had a direct effect on milk FA composition. Feeding of GRS appeared to beneficially alter the nutritional status of milks with greater than 2-fold increases in total concentration of CLA, particularly the health benefitting isomer CLA cis-9,trans-11 offering further confirmation to previous studies that revealed an association between increased milk CLA and fresh grass feeding. Pasture feeding systems resulted in significantly higher contents of n-3 FA and significantly lower contents of n- 6 FA than that of TMR milk, which also had a significantly higher thrombogenic index than that of pasture-derived milks. Finally, this study further indicated the possibility of FA profiling of milk for verification of fresh pasture feeding systems over that of TMR systems.

\section{ACKNOWLEDGMENTS}

This publication has emanated from research conducted with the financial support of Science Foundation Ireland (SFI) under Grant Number SFI/12/RC/2273, Teagasc, and the Dairy Levy Fund administered by Dairy Research Ireland. Tom F. O'Callaghan is the recipient of a Teagasc Walsh Fellowship. The valuable input of Elaine Patterson and David Mannion (Teagasc Moorepark, Ireland) is gratefully acknowledged, and Jimmy Flynn (Teagasc Moorepark, Ireland) is thanked for technical assistance over the course of the experiment. The input of Sean Lacey (Department of Mathematics, Cork Institute of Technology, Ireland) for statistical analysis is very much appreciated. The authors sincerely thank the technical and farm staff at Teagasc Moorepark for their excellent care of the experimental cows and assistance during the experiment.

\section{REFERENCES}

Adler, S. A., S. K. Jensen, E. Govasmark, and H. Steinshamn. 2013. Effect of short-term versus long-term grassland management and seasonal variation in organic and conventional dairy farming on the composition of bulk tank milk. J. Dairy Sci. 96:5793-5810.

Amenu, B., T. Cowan, H. Deeth, and R. Moss. 2006. Impacts of feeding system and season on milk composition and Cheddar cheese yield in a subtropical environment. Anim. Prod. Sci. 46:299-306. 
Auldist, M. J., B. J. Walsh, and N. A. Thomson. 1998. Seasonal and lactational influences on bovine milk composition in New Zealand. J. Dairy Res. 65:401-411.

Baer, R. J., J. Ryali, D. Schingoethe, K. Kasperson, D. Donovan, A. Hippen, and S. Franklin. 2001. Composition and properties of milk and butter from cows fed fish oil. J. Dairy Sci. 84:345-353.

Baltušnikienè, A., Z. Bartkevičiūtė, and J. Černauskienė. 2008. Fatty acids content and composition of milk fat from cows consuming pasture and total mixed ration. Veterinarija IR Zootechnika T $42: 28-33$

Barberg, A. E., M. Endres, J. Salfer, and J. Reneau. 2007. Performance and welfare of dairy cows in an alternative housing system in Minnesota. J. Dairy Sci. 90:1575-1583.

Bargo, F., L. Muller, J. Delahoy, and T. Cassidy. 2002. Performance of high producing dairy cows with three different feeding systems combining pasture and total mixed rations. J. Dairy Sci. 85:29482963.

Benbrook, C. M., G. Butler, M. A. Latif, C. Leifert, and D. R. Davis. 2013. Organic production enhances milk nutritional quality by shifting fatty acid composition: A United States-wide, 18-month study. PLoS ONE 8:e82429.

Capuano, E., G. Van der Veer, R. Boerrigter-Eenling, A. Elgersma, J. Rademaker, A. Sterian, and S. M. Van Ruth. 2014. Verification of fresh grass feeding, pasture grazing and organic farming by cows farm milk fatty acid profile. Food Chem. 164:234-241.

Caradus, J., D. Woodfield, and A. Stewart. 1996. Overview and vision for white clover. Special Publication-Agronomy Society of New Zealand.

Castillo, A. R., M. A. Taverna, R. R. Páez, A. Cuatrin, D. Colombatto, F. Bargo, M. S. García, P. T. García, M. Chavez, and A. D. Beaulieu. 2006. Fatty acid composition of milk from dairy cows fed fresh alfalfa based diets. Anim. Feed Sci. Technol. 131:241-254.

Charlton, G. L., S. M. Rutter, M. East, and L. A. Sinclair. 2011. Preference of dairy cows: Indoor cubicle housing with access to a total mixed ration vs. access to pasture. Appl. Anim. Behav. Sci. 130:1-9.

Couvreur, S., C. Hurtaud, C. Lopez, L. Delaby, and J.-L. Peyraud. 2006. The linear relationship between the proportion of fresh grass in the cow diet, milk fatty acid composition, and butter properties. J. Dairy Sci. 89:1956-1969.

De Jong, C., and H. T. Badings. 1990. Determination of free fatty acids in milk and cheese procedures for extraction, clean up, and capillary gas chromatographic analysis. J. High Resolut. Chromatogr. 13:94-98.

DePeters, E. J., and J. D. Ferguson. 1992. Nonprotein nitrogen and protein distribution in the milk of cows. J. Dairy Sci. 75:3192-3209.

Dhiman, T. R., G. Anand, L. Satter, and M. Pariza. 1999. Conjugated linoleic acid content of milk from cows fed different diets. J. Dairy Sci. 82:2146-2156.

Egan, M., M. Lynch, and D. Hennessy. 2013. The influence of white clover inclusion in perennial ryegrass swards on milk and herbage production in a high $\mathrm{N}$ fertiliser system. In Proc. Agricultural Research Forum.

Egan, M., M. Lynch, D. Hennessy, A. Pol-van Dasselaar, H. Aarts, A. d. Vliegher, A. Elgersma, D. Reheul, J. Reijneveld, and J. Verloop. 2015. Herbage and milk production from a grass-only sward and grass-white clover swards in an intensive grass-based system. Pages 93-95 in Proc. Grassland and Forages in High Output Dairy Farming Systems. Proceedings of the 18th Symposium of the European Grassland Federation, Wageningen, the Netherlands. Wageningen Academic Publishers, Wageningen, the Netherlands.

Fehily, A. M., J. Pickering, J. Yarnell, and P. C. Elwood. 1994. Dietary indices of atherogenicity and thrombogenicity and ischaemic heart disease risk: The Caerphilly Prospective Study. Br. J. Nutr. $71: 249-257$.

Fregonesi, J. A., D. Veira, M. von Keyserlingk, and D. Weary. 2007. Effects of bedding quality on lying behavior of dairy cows. J. Dairy Sci. 90:5468-5472.

Glover, K. E., S. Budge, M. Rose, H. Rupasinghe, L. Maclaren, J. Green-Johnson, and A. Fredeen. 2012. Effect of feeding fresh for- age and marine algae on the fatty acid composition and oxidation of milk and butter. J. Dairy Sci. 95:2797-2809.

Guinee, T., E. Mulholland, B. O'Brien, and J. Murphy. 2001. Effect of diet quality on the suitability of mid-lactation bovine milk for cheddar cheese manufacture. Aust. J. Dairy Technol. 56:3.

Harris, S., D. Clark, M. Auldist, C. Waugh, and P. Laboyrie. 1997 Optimum white clover content for dairy pastures. Pages 29-34 in Proc. New Zealand Grassland Association. New Zealand Society of Animal Production, Hamilton.

Harris, S. L., M. J. Auldist, D. A. Clark, and E. B. Jansen. 1998. Effects of white clover content in the diet on herbage intake, milk production and milk composition of New Zealand dairy cows housed indoors. J. Dairy Res. 65:389-400.

Harstad, O. M., H. Steinshamn, and M. Griffiths. 2010. Cows' diet and milk composition. Improving the safety and quality of milk. Milk Production and Processing 1:223-245.

Haskell, M. J., L. Rennie, V. Bowell, M. Bell, and A. Lawrence. 2006. Housing system, milk production, and zero-grazing effects on lameness and leg injury in dairy cows. J. Dairy Sci. 89:4259-4266.

Hurtaud, C. and J. Peyraud. 2007. Effects of feeding camelina (seeds or meal) on milk fatty acid composition and butter spreadability. J. Dairy Sci. 90:5134-5145.

INRA. 2007. Alimentation des bovins, ovins et caprins. Éditions Quæ. INRA, Paris, France.

ISO. 2001. Milk-Determination of nitrogen content. Part 1 in Kjeldahl Method ISO 8968-1: 2001 (IDF 20-1:2001). International Standardization Organization, Geneva, Switzerland.

ISO. 2004. Milk-Determination of casein-nitrogen content. Part 1 in Indirect Method. Vol. ISO-17997-1. International Standardization Organization, Geneva, Switzerland.

Kay, J. K., J. R. Roche, E. S. Kolver, N. A. Thomson, and L. H. Baumgard. 2005. A comparison between feeding systems (pasture and TMR) and the effect of vitamin E supplementation on plasma and milk fatty acid profiles in dairy cows. J. Dairy Res. 72:322-332.

Kelly, M. L., E. Kolver, D. Bauman, M. Van Amburgh, and L. Muller. 1998. Effect of intake of pasture on concentrations of conjugated linoleic acid in milk of lactating cows. J. Dairy Sci. 81:1630-1636.

Kennedy, E., E. Lewis, J. Murphy, N. Galvin, and M. O'Donovan. 2015. Production parameters of autumn-calving cows offered either a total mixed ration or grazed grass plus concentrate during early lactation. J. Dairy Sci. 98:7917-7929.

Koba, K., and T. Yanagita. 2014. Health benefits of conjugated linoleic acid (CLA). Obes. Res. Clin. Pract. 8:e525-e532.

Kolver, E., A. Napper, P. Copeman, L. Muller, and S. Peterson. 2000. A comparison of New Zealand and overseas Holstein Friesian heifers. Pages 265-269 in Proc. New Zealand Society of Animal Production. New Zealand Society of Animal Production, Hamilton.

Lee, M. R., V. Theobald, J. Tweed, A. Winters, and N. Scollan. 2009 Effect of feeding fresh or conditioned red clover on milk fatty acids and nitrogen utilization in lactating dairy cows. J. Dairy Sci. 92:1136-1147.

Legrand, A. L., M. Von Keyserlingk, and D. Weary. 2009. Preference and usage of pasture versus free-stall housing by lactating dairy cattle. J. Dairy Sci. 92:3651-3658.

Lock, A., and P. Garnsworthy. 2003. Seasonal variation in milk conjugated linoleic acid and $\Delta$ 9-desaturase activity in dairy cows. Livest. Prod. Sci. 79:47-59.

Lucey, J. 1996. Cheesemaking from grass based seasonal milk and problems associated with late-lactation milk. Int. J. Dairy Technol. 49:59-64

McCarthy, B., M. Egan, and D. Hennessy. 2016. Opportunities and risks of combining high inputs of inorganic $\mathrm{N}$ with forage legumes. Legume Perspectives 12:29-30.

Medrano, J., A. Johnson, E. DePeters, and A. Islas. 1999. Genetic modification of the composition of milk fat: Identification of polymorphisms within the bovine stearoyl-CoA-desaturase gene. J. Dairy Sci. 82:(Suppl. 1):71. (Abstr.)

Minson, D. 1990. Forage in Ruminant Nutrition. Academic Press Inc., London, UK.

Moorby, J. M., M. R. Lee, D. Davies, E. J. Kim, G. Nute, N. Ellis, and N. D. Scollan. 2009. Assessment of dietary ratios of red clover and 
grass silages on milk production and milk quality in dairy cows. J. Dairy Sci. 92:1148-1160.

O'Brien, B., P. Dillon, J. Murphy, R. K. Mehra, T. P. Guinee, J. F. Connolly, A. Kelly, and P. Joyce. 1999. Effects of stocking density and concentrate supplementation of grazing dairy cows on milk production, composition and processing characteristics. J. Dairy Res. 66:165-176.

O'Neill, B. F., M. Deighton, B. O'Loughlin, F. Mulligan, T. Boland, M. O'Donovan, and E. Lewis. 2011. Effects of a perennial ryegrass diet or total mixed ration diet offered to spring-calving HolsteinFriesian dairy cows on methane emissions, dry matter intake, and milk production. J. Dairy Sci. 94:1941-1951.

Palmquist, D. L., and T. Jenkins. 1980. Fat in lactation rations. J. Dairy Sci. 63:1-14. (Review).

Patterson, E., R. Wall, G. Fitzgerald, R. Ross, and C. Stanton. 2012. Health implications of high dietary omega- 6 polyunsaturated fatty acids. J. Nutr. Metab. 2012:539426.

Pfeuffer, M., and J. Schrezenmeir. 2000. Bioactive substances in milk with properties decreasing risk of cardiovascular diseases. Br. J. Nutr. 84(Suppl. 1):S155-S159.

Piperova, L., B. Teter, I. Bruckental, J. Sampugna, and R. Erdman. 1998. Association of diet induced increases in milk trans fatty acids with the activities of acetyl-CoA carboxylase and fatty acid synthetase in the mammary gland of lactating dairy cows. J. Dairy Sci. 80:352.

Puppel, K., B. Kuczyńska, T. Nałęcz-Tarwacka, and H. Grodzki. 2013. Influence of linseed variety on fatty acid profile in cow's milk. J. Sci. Food Agric. 93:2276-2280.

Ramaswamy, N., R. Baer, D. Schingoethe, A. Hippen, K. Kasperson, and L. Whitlock. 2001. Composition and flavor of milk and butter from cows fed fish oil, extruded soybeans, or their combination. J. Dairy Sci. 84:2144-2151.

Reynolds, C. 2006. Production and metabolic effects of site of starch digestion in dairy cattle. Anim. Feed Sci. Technol. 130:78-94.

Ribeiro Filho, H., R. Delagarde, and J. Peyraud. 2005. Herbage intake and milk yield of dairy cows grazing perennial ryegrass swards or white clover/perennial ryegrass swards at low-and medium-herbage allowances. Anim. Feed Sci. Technol. 119:13-27.

Santos, J. E. P. 2002. Feeding for milk composition. Pages 163-172 in Proc. VI International Congress on Bovine Medicine. Spanish Association of Specialists in Bovine Medicine (ANEMBE), Santiago de Compostela, Spain
Schroeder, G., J. Delahoy, I. Vidaurreta, F. Bargo, G. Gagliostro, and L. Muller. 2003. Milk fatty acid composition of cows fed a total mixed ration or pasture plus concentrates replacing corn with fat. J. Dairy Sci. 86:3237-3248.

Šimat, V., T. Bogdanović, V. Poljak, and S. Petričević. 2015. Changes in fatty acid composition, atherogenic and thrombogenic health lipid indices and lipid stability of bogue (Boops boops Linnaeus, 1758 ) during storage on ice: Effect of fish farming activities. J. Food Compos. Anal. 40:120-125.

Siri-Tarino, P. W., S. Chiu, N. Bergeron, and R. M. Krauss. 2015 Saturated fats versus polyunsaturated fats versus carbohydrates for cardiovascular disease prevention and treatment. Annu. Rev. Nutr. 35:517.

Slots, T., G. Butler, C. Leifert, T. Kristensen, L. H. Skibsted, and J H. Nielsen. 2009. Potentials to differentiate milk composition by different feeding strategies. J. Dairy Sci. 92:2057-2066.

Stanton, C., F. Lawless, G. Kjellmer, D. Harrington, R. Devery, J. Connolly, and J. Murphy. 1997. Dietary influences on bovine milk cis-9, trans-11-conjugated linoleic acid content. J. Food Sci. 62:1083-1086.

Thomson, D. 1984. The nutritive value of white clover. Pages 78-92 in Proc. Forage Legumes. Occasional Symposium. British Grassland Society, UK.

Ulbricht, T., and D. Southgate. 1991. Coronary heart disease: Seven dietary factors. Lancet 338:985-992.

Ulyatt, M. 1981. The feeding value of herbage. Can it be improved? N. Z. J. Agric. Sci. 15:200-205.

van Arendonk, J. A., and A.-E. Liinamo. 2003. Dairy cattle production in Europe. Theriogenology 59:563-569.

Verkerk, G. 2003. Pasture-based dairying: Challenges and rewards for New Zealand producers. Theriogenology 59:553-561.

White, S., J. Bertrand, M. Wade, S. Washburn, J. Green, and T. Jenkins. 2001. Comparison of fatty acid content of milk from Jersey and Holstein cows consuming pasture or a total mixed ration. J. Dairy Sci. 84:2295-2301.

Whiting, C. T. Mutsvangwa, J. Walton, J. Cant, and B. McBride. 2004. Effects of feeding either fresh alfalfa or alfalfa silage on milk fatty acid content in Holstein dairy cows. Anim. Feed Sci. Technol. 113:27-37.

Wolfschoon-Pombo, A., and H. Klostermeyer. 1981. The NPN-fraction of cow milk I. Amount and composition. Milchwissenschaft $36: 598-600$. 